\title{
Innovations at Cannes
}

\author{
By Ron Holloway
}

Fall 2000 Issue of KINEMA

\section{CANNES: INNOVATIONS IN THE CERTAIN REGARD, DIRECTORS' FORTNIGHT AND CRITICS WEEK}

For the third year in a row, an entry in Un Certain Regard was awarded the increasingly important prize of the Fondation GAN pour le cinéma (worth FF 200,000 in French distribution aid) by an independent international jury. Consequently this Cannes sidebar is now viewed by many as a "backup festival" to the Competition in the official program. For the second year in a row under the new management of MariePierre Macia, the Quinzaine des Réalisateurs (Directors' Fortnight) continued to distance itself from the prior policies of Pierre-Henri Deleau (three decades on the job) by formulating a programming image that was even more actor-and-personality oriented than last year's event. And for the first time in 16 years, the Semaine de la critique (Critics Week) finds itself under new management: José María Riba was elected by the Paris-based critics to replace Jean Roy on the job.

\section{UN CERTAIN REGARD VIEWS}

Two years ago, in 1998, the Fondation GAN pour le cinéma awarded its prize for the first time to Darezhan Omirbaev's Tuer à gages (Killer, Kazakhstan-France). In 1999, it went to Jasmin Dizdar's Beautiful People (UK). This year, the jury, headed by actress Jane Birkin, gave its prize to Rodrigo Garcia's Things You Can Tell Just by Looking at Her (USA), a collection of five vignettes about intertwined relationships shared by a group of men and women. Herewith some random comments on seven other films from around the world that were selected for programming in the Certain Regard, regarded by many festival directors as a fertile hunting-ground for entries to programme in their own competitions:

\section{Le premier du nom (First of the Name, France-Switzerland), Sabine Franel}

Sabine Franel, better known as a film editor, has collaborated in the past with Portuguese master Mañoel de Oliveira (Les Cannibales, 1988 Cannes entry), João Canjo, Claude Weisz, and Emil Weisz.. On separate occasions she has directed three candid, insightful short films: Les Bottes de défunct (The Boots of the Deceased, 1979), a documentary about an auction in a provincial town, Leyla Zana, la Pasionaria des Kurdes (Leyla Zana, the Pasionaria of the Kurds, 1996), and Bloc-notes (Notebook, 1997). Her first feature film, Le Premier du nom (First of the Name), contended for Camera d'Or honours.

Conceived as a film project twelve years ago and seven years in the making, First of the Name follows two genealogy zealots on a quest: they want to assemble as many descendants of Moîse Blin as possible to see what can be discovered about the man and the times in which he lived. Moîse Blin was an Alsatian Jewish peddler of the 18th century. When several descendants gather to join in the quest - one of whom is Sabine Franel herself - the chronicles of this scattered yet linked family reach back to 1768 and carry up to the present day. Filmed appropriately in black-and-white, this gives the film an extra documentary edge commensurate with the quasi-documentary's thematic range: family reunions, family history, individual life-stores, and, best of all, a fascinating and exemplary history of the European Jew from persecution to assimilation.

\section{Oh! Soo-jung (South Korea), Hong Sang-soo}

The Korean New Wave is the talk of Far East cinema, due to a double-decker October event known as the Pusan International Film Festival (PIFF) and the Pusan Promotion Plan (PPP) that for the past four years has been effectively promoting the cause of Asian cinema as a whole. Korean cinema of the 1980s changed dramatically for the better when veteran director Im Kwon-taek was joined by a group of filmmakers who emerged from, or were influenced by, a phalanx of documentary and short film directors, each with a personal vision. Thus it was no accident that Cannes 2000 booked Korean entries in all major sections: Im Kwontaek's Chungyang (Competition), a sumptuously costumed folk opera set in the 18th century and narrated by a pansori singer to a mesmerized audience; Hong Sang-soo's Oh! Soo-jung (Certain Regard), a modern tale of love and desire in a troika context; Lee Chang-dong's Peppermint Candy (Directors' Fortnight), a chronicle of two decades of postwar North-South Korean history as experienced by an ex-businessman contemplating 
suicide; and Jung Ji-woo's Happy End (Critics Week), the story of a wife and mother's illicit affair with a former college boyfriend and how this affects her family when the secret is out.

Born 1961 in Seoul, Sang-soo Hong studied cinema at Chung-Ang University and film schools in California, Chicago, and Paris. Returning to Korea, he was working for the Seoul Broadcasting Station when he made The Day a Pig Fell in the Well (1996) on the side. Scored a discovery at the 1st Pusan festival, this low-budget tale of a fragile relationship between a would-be novelist and a married woman was booked immediately for festival programming around the world. Asked to comment on the film's success, Hong responded: "I am not a storyteller. A so-called story has its characters fixed, at least to some degree. I, on the other hand, stress the attitudes of the characters. Given a situation, characters assume various attitudes and those, combined with my own, make my film. This, I think, is also the theme of my film."

Two years later, Hong was a key figure at the 3rd Pusan festival after his critically praised, written-anddirected The Power of Kangwon Province (1998) was invited to participate in the Certain Regard section at Cannes. Set during a hot summer in Seoul, it explores the relationship of a young woman to a married university professor, their painful break-up, and then even more painful encounter on separate outings to the same mountain temples of Kangwon Province - after which, they return home lonelier than before. This time, Hong had expanded his vision to focus on the foibles of human behaviour: drunken spats, joyless flirtations, a missed rendezvous, an affair with a prostitute. Hong's latest feature, Oh! Soo-jung, can be viewed as the third part of a trilogy on "love and desire between ordinary people." Two men, Jae Hoon (Bosuk Jung) and Young-soo (Sung-keun Moon), art students at the same college, one older than the other, are attracted to the same girl: Soo-jung (Eun Joo Lee). Since the woman is a virgin, and one man is more experienced than the other, the relationships among the trio become more complex as passions force changes in character and attitude.

\section{Wild Blue (Belgium-France-Austria), Thierry Knauff}

Thierry Knauff spent seven years making Wild Blue, and you have to believe him. Only Werner Herzog can compare with the dedication of this Belgian filmmaker who lived for months among the Pygmies to shoot Baka (1995). A Belgian-French co-production, Baka was awarded the Golden Conch at the 4th Mumbai (Bombay) International Film Festival for Documentary, Short \& Animation Films in 1996. It was shot over a period of several months in the equatorial rain-forests of southeast Cameroon, where mahogany and ebony trees are being exploited for commercial gain. In addition, this hour-long portrait of a primitive people describes in contrasting black-and-white images the daily rituals and struggle for existence of the Baka Pygmies. Although in one sense an ethnographic film, it contains dramatic and narrative elements that leave no doubt that the Pygmies too may be a vanishing race if conditions continue as they are in the rain-forest.

Born 1957 in Kinshasa and a graduate from the department for film directing at INSAS in Bruxelles, Thierry Knauff has been awarded a number of prizes for his short documentaries: Fin octobre début novembre (End of October, Beginning of November, 1983), Le Sphinx (1986), Abattoirs (1987), Seuls (Alone, 1989), Anton Webern (1991), Gbanga-Tita (1994), and Baka (1995). When not on the road to Africa and elsewhere, he programs films at the Cinémathèque Royale in Bruxelles. One of his confessed favourites is Fredi M. Murer's Höhenfeuer (Alpine Fire, 1985), a Swiss film about incest that's set high in the Alps and isolated from the communities below.

As for Wild Blue, Knauff's first feature film and a candidate for Camera d'Or honours, it was inspired by his Anton Webern documentary. The director describes it as a "tone poem" taken from scattered bits or pieces of previously shot film footage (or "notes for several voices") that had never been included in his other films. These "musical motifs" in black-and-white are female voices and children at play, the sounds of wind and the rustle of trees, the babble of languages: French, German, English, Farsi, Kineruanda, Beti, Hindi, Serbo-Croat, and Arabic. Punctuated with silence and songs, Wild Blue unfolds as a statement on a world afflicted by civil disorders and religious atrocities. "It seems to me that there is a permanent tension between a world that we know to be rife with extremes of intolerance and violence and, at the same time, a world of profound beauty despite the prevailing horror."

Jacky (Netherlands), Brat Ljatifi, Pyng Hu Fow

Following its discovery at the Rotterdam festival last February, Jacky introduced at Cannes a tandem 
directorial team with a common base in Amsterdam. Before collaborating on this debut feature (contending for Camera d'Or honours), Brat Ljatifi and Pyng Hu Fow had separately made a series of videos, short films, and documentaries. Then, two years ago, when Ljatifi fashioned a script drawn from everyday immigrant Chinese life, Fow stepped in to play the title role himself. The pair edited the film together.

"We like the movies of Taiwan directors Tsai Ming Liang (Vive l'Amour, Venice 1994) and Hou Hsiao Hsien (Goodbye South, Goodbye, Cannes 1996)," confirmed Ljatifi and Fow in an interview. Thus, if you apply the stylistic aesthetics of those directors to Jacky, you have a quiet, observant, searching story in which the key characters - mother, son, wife, friend - derive their personalities from traditional cultural attitudes and are motivated in their actions by immediate surroundings and the people they associate with. And since their thoughts are often difficult to articulate, their actions are sometimes contradictory and dialogue painfully sparse. For this reason, it's the strikingly composed images (camera Benito Strangio) and attention to minute visual detail that tell most of the story.

Jacky (Pyng Hu Fow), 31, an easy-going railway waiter, lives in Eindhoven with his widowed mother (Xuan Weizhuo), who arrived in Holland long ago with her husband to run a Chinese restaurant. Nowadays, she does little more than care for the garden, watch the days pass, and worry about the status of an unmarried son. Tradition requires that he marry a Chinese girl, so when she arranges for a mail-order bride to arrive on the scene, Jacky has little alternative but to bow to custom. As for Chi-Chi, the girl feels as alienated in her new surroundings as Jacky does trying to figure out what to do with this unexpected turn in his life. The manner is made even more complicated when Gary (Gary Guo), a travel guide and entertainer for Chinese tourists, takes an extra special interest in Jacky - and raises sheer havoc when he invites himself to sing at a birthday party for Jacky's mother.

\section{Abschied (The Farewell, Germany), Jan Schütte}

Jan Schütte has an enviable festival cum award record. Particularly, those feature films made in collaboration with the late and remarkably gifted writer-playwright-screenwriter Thomas Strittmatter were highwater marks in contemporary German cinema. The pair's first feature film, Drachenfutter (Dragon's Food, 1987), about a Pakistani and a Chinese opening a multi-culti restaurant in Hamburg, was selected for the Opera Prima section at Venice and was awarded the German Critics Prize and the Prix François Truffaut. Their second feature, Winckelmanns Reisen (Winckelmann's Journeys, 1990), a road-movie about a Willy Lohman salesman criss-crossing the provinces of northern Germany, was awarded a CICAE Prize. And Goodbye America (1994), about an elderly Jewish-Polish immigrant couple living in New York, was invited to the Directors' Fortnight and awarded a German Film Prize in Silver and the Bavarian Film Prize. It was the pair's last film together before Strittmatter's premature death.

Schütte returned to Cannes with one of the most fascinating German films of the season: Abschied (The Farewell), also known as Buckower Elegien and The Bertolt Brecht Story. "It's quite different from my other films," Schütte points out. "This is a fictional story, although at the same time an authentic one. We're more interested in showing the situation of a great writer who has encountered many difficult situations in his converging private, political, and artistic lives." The "we" refers to screenwriter Klaus Pohl and actor Josef Bierbichler, a Bavarian like Brecht, who collaborated on the project.

Set on one of the last days of an unusually hot summer, just before his death in 1956, Bertolt Brecht is surrounded by close friends and former lovers at his lakeside villa near the Brandenburg town of Buckow north of Berlin. Shortly, he will leave for Berlin and the Berliner Ensemble to begin the new season. But right now he wants to look back on his past life, reflect on the political upheaval stemming from Stalin's recent death, and review his role as a dramatic force on the German and international scene. His wife Helene Weigel is on hand, as are his daughter Barbara Berg, his former lover Ruth Berlau, his latest flame Käthe Reichel, and the dissident Wolfgang Harig. Over the course of the day - "from seven in the morning to five in the afternoon" the peaceful setting erupts into a storm of raw emotions until Brecht finds himself at the very centre of the controversy.

Nichiyobi Wa Owaranai (Sunday's Dream, Japan), Yoichiro Takahashi

With but two feature films to his name, Yoichiro Takahashi has risen swiftly to the front ranks of a new generation of Japanese filmmakers. His first feature Fishes in August (1997), awarded in 1998 the New Directors Prize at San Sebastian and the Grand Prize at Thessaloniki, scored as a quiet, sensitive exploration 
on a secondary schoolboy's feelings on the verge of adulthood. Based on a novel by Natsuo Sekikawa, it comes across as a poignant, lyrical story of an outsider forced to compete in order to prove his worth as an individual, win the respect of his chums on the swimming team, and attract the attention of the girl he's fallen in love with. The title is taken from its summer setting at Tokyo Bay, stylistically enhanced by motifs taken from water imagery: swimming pools, showers, hoses, faucets, an aquarium, the bay itself.

Born 1963 in Tokyo, Yoichiro Takahashi joined the Japan Broadcasting Corporation (NHK) immediately after graduation from the university. His psychologically persuasive documentaries and short films, particularly Yoko (1992) and Violent Teacher (1996), paved the way for the subtle and visually expressive exploration of raw emotions in Fishes in August. His experience at NHK also opened the door to tele-feature productions shot on HDTV, the format chosen for his second feature film Sunday's Dream.

A story told on two levels, the past and the present, Sunday's Dreamwas scripted by Ryo Iwamatsu, a dramatist esteemed for his talent to sketch human behaviour and psychological relations. Although a tragedy, the story also has its comic and touching moments. Kazuya - played by Kenji Mizuhashi, the lead in Fishes in August - is again one of those bad-luck kids who doesn't know why fate is always against him. First, he gets fired from his job by his own father, who is required to let workers go on a company policy of redundancy. Then, when he goes to live with his separated mother, she evicts him on the grounds that she plans to remarry. A ray of hope enters his life, however, when Kazuya meets Sachiko at a local "sex salon" and makes a date for the following Sunday. That "Sunday dream" has to wait years for fulfilment - for on the day the two are to meet the distraught lad kills his mother's new husband in a fit of violent rage. Several years later, Kazuya leaves prison to start life anew - and decides to look for Sachiko to rekindle the emotions of that fateful Sunday.

\section{Lost Killers (Germany), Dito Tsintsadze}

Georgian director Dito (sometimes signed Dmitry) Tsintsadze burst on the international scene in 1993, when his On the Edge was awarded a Silver Leopard at the Locarno festival. This laconic tale, set in Tbilisi on the eve of the Georgian civil war, records in minute detail the psychological pressure exerted on a young man, an idle observer in a nearly abandoned city, to maintain his independence despite the contradictions of his stance. For if he chooses to remain neutral, he will eventually lose contact with friends and surroundings, thus isolating himself all the more and forcing himself to commit an uncontrolled act of violence. Ironically, On the Edge placed Tsintsadze in the front ranks of Georgian filmmakers at the very time when production at the Gruzia Studios had ground to a standstill. For the next seven years he was without work.

Born 1957 in Tbilisi, Dito Tsintsadze studied at the Georgian Institute for Film and Theatre (1975-81), made a handful of short films, and worked as an assistant for other directors. His first two medium-length feature films marked him as a director with a feel for atmosphere and the foibles of human behaviour. Guests (1991), about a family receiving unexpected visitors, escalates to a level of mad absurdity when it becomes evident that no one is quite sure who these guests are in the first place. In Home (1991) the focus is on a young woman who lives in a milieu of apathy, plainness, and indifference. Both films served as etudes for the discordant study of the vacillating young man in On the Edge.

In Lost Killers, a tragicomedy shot in Mannheim with financial backing by Berlin producer Peter Rommel, Dito Tsintsadze has his cameraman (Benedict Neuenfels) follow a pair of hapless, fumbling hitmen around the city as they stalk their prey. Not even Branko (Misel Maticevic) and Merab (Lasha Bakradze) know why they are to rub out the unsuspecting businessman, much less find him in the first place at the right time to do the job. Each time a ripe opportunity presents itself, something absurd and coincidental stops the pair. So the "lost killers" enlist Carlos (Elie Blezes), an oversized Haitian fugitive, and Lan (Nicole Seelig), a pint-sized Vietnamese prostitute, to help get the job done - and end up with an unexpected and unexplained murder on their hands.

\section{Djomeh (Iran-France), Hassan Yektapanah}

"My long association with Abbas Kiarostami was a great blessing for me," said Hassan Yektapanah in an interview with the Iranian journal Film International. "He not only taught me cinema, but how to look at the world." Awarded a share of the Camera d'Or for best first feature film - together with fellow Iranian filmmaker Bahman Ghobadi's Zamani barayé masti asbha (A Time for Drunken Horses, Directors' Fortnight entry) - Yektapanah's Djomeh took a year to complete and was seven months in post-production. Reason? The 
director is a perfectionist: he wrote, directed, edited, and set-designed Djomeh - initially titled Relationship, then changed because it sounded "too professional and commercial."

Born 1963, Hassan Yektapanah is one of those committed artists who started his film career very young. First he was simply part of a production crew, then worked his way up to become first assistant director to the late Ali Hatami, Tahmineh Milani, Jafar Panahi ( The Mirror), Ebrahim Forouzesh (The Little Man), and finally Abbas Kiarostami (The Taste of Cherry, The Wind Will Carry Us). After 14 years of watching film production in close-up, Yektapanah penned a script, honed it to his liking, and handed it to Kiarostami. He, in turn, liked Djomeh enough to help Yektapanah find a producer, then visited the set during the shooting, and eventually contacted a French co-producer.

Djomeh is the story of three lonely people. The young Djomeh (Jalil Nazari) is one of two Afghan labourers who work on a dairy farm in the remote Iranian countryside for a middle-aged diary owner who never married. Each morning, they accompany the owner to nearby villages to buy milk that will be turned on the farm into diary products for sale. During these outings, due to Djomeh's outgoing personality and desire to strike up a conversation, they begin to talk - "about ideas, ideals, society, world views, and philosophy," as Hassan Yektapanah put it in the Film International interview. "I made every effort to keep the film realistic. I tried to make the camera and acting imperceptible, so that the dialogues and everything else would be very similar to ordinary routine life. That's all I can say about the film."

Djomeh, it should be added, is not only about the pain of loneliness and the need to talk. When Djomeh falls in love with Setareh (Mahbobeh Khalili), a local girl, he turns to the diary owner Mahmoud (Mahmoud Behraznia) to serve as chaperon. A bold gesture, for Djomeh is crossing cultural boundaries - and strict Iranian courtship customs do not allow for open courtship.

\section{DIRECTORS' FORTNIGHT FOOTNOTES}

Of the 24 official entries in the Quinzaine des Réalisateurs, all were listed as either world premieres or international premieres (released only in the country of production), eleven were candidates for the Camera d'Or prize, and ten were French productions or co-productions. One common trait, according to Marie-Pierre Macia, linked all the entries: "the singularity of these filmmakers' visions, a feeling of jamais vu." Herewith a collection of notes on 15 films programmed in the Directors' Fortnight:

\section{Zamani barayé masti asbha (A Time for Drunken Horses, Iran), Bahman Ghobadi}

Although A Time for Drunken Horses shared Camera d'Or honours for best debut feature film at Cannes (with the aforementioned Djomeh by fellow Iranian filmmaker Hassan Yektapanah), its director Bahman Ghobadi is an all-around talent on the Iranian film scene. Born 1969 in Bané in northeast Iran, he made several short films and documentaries before assisting Abbas Kiarostami on The Wind Will Carry Us, a 1999 Venice entry. Also, he can be seen as an actor in Samira Makhmalbaf's Takhté siah (Blackboards), this year's Cannes Competition entry - in fact, Bahman Ghobadi plays the lead role: the teacher Reeboir, who wanders across mountainous paths with a blackboard on his back to attract students to attend makeshift classes and learn to read and write. Moreover, A Time for Drunken Horses and Blackboards have much more in common than first meets the eye: both were shot in Iranian Kurdistan, a barren landscape of austere mountains, impoverished people, and politically sensitive cultural issues.

Bahman Ghobadi began making short films at 26. All are socially oriented with an eye for the human and the personal: That Man Has Arrived (1995), Again Rain with the Song (1995), Dang (1996), Part of the Notebook (1996), God's Fish (1996), Like Mother (1996), The Reception (1996), To Live in a Fog (1998), and Melodies of a Girl from the Steppes (1998). The best known of these, To Live in a Fog, was awarded at several international film festivals. Along the way, the actor-director formed his own production company, Bahman Ghobadi Films, to write, direct, and produce A Time for Drunken Horses.

Shot in and around Bané (where Ghobadi was born) and in the language of the inhabitants (Kurdish and Persian), A Time of Drunken Horses is the poignant story of children having to provide for themselves in Iranian Kurdistan near the Iraqi border. When the younger of two brothers falls seriously ill and needs an immediate operation, the older sister, who has been providing for the family, agrees to a marriage with an Iraqi on the condition that money will be given for the operation. When they reach the border, however, the 
future husband's family refuses to have the sick youth accompany the sister. Instead, the boys are given a horse that will help them to earn a living. For this neorealist film constructed around actual events, Bahman Ghobadi has chosen nonprofessional actors from the same family - Nezhad, Amaneh, and Madi Ektiar-Dini - to play the lead roles, together with inhabitants from the villages of Sardab and Bané.

\section{Missing Kisses (Germany-Georgia-France-UK), Nana Djordjadze}

Georgian director Nana Djordjadze (spelled Jorjadze in English) is no stranger to the Cannes film festival. Her debut feature film Robinsonade, or My English Grandpa, 1986), a Certain Regard entry in 1987, was awarded the prestigious Camera d'Or. Five years later, in 1992, she was invited to serve on the International Jury. Four years later, in 1996, she presented A Chef in Love in the Directors' Fortnight - and this quaint French-Georgian comedy, with Pierre Richard in the title role, went on from there to be nominated for an Oscar. Now she's back in the Fortnight again with 27 Missing Kisses (originally titled Summer), produced by Jens Meurer and Oliver Damian at Berlin-based Egoli Films and with Pierre Richard in an uproarious comic cameo as a French captain looking for the sea.

Billed as a tragicomedy about sex and life in the former Soviet Union, 27 Missing Kisses is scripted by Irakli Kvirikadze, Nana's husband, who knows the absurdities of socialist life and mores - particularly its notoriously hidden libido - like the back of his hand. It was the mapcap, ribald, original Irakli who penned for Nana Robinsonade and A Chef in Love, for Bakhtiar Khudoinazarov Luna Papa (Venice entry, 1999), and for himself The Swimmer (1980) and The Journey of Comrade Stalin to Africa (1990), the former banned for seven years and the latter still a scandal in some Eastern European countries. As separate talents, writerdirector Kvirikadze and director-actress Djordjadze have bagged a score of FIPRESCI and international festival awards. As a team, they're next to unbeatable.

In 27 Missing Kisses, set in a "sleepy Eastern town," the 14-year-old Sybille (Nino Kukhanidze) arrives on the scene to spend the summer vacation with her aunt. There she falls in love with the middle-aged widower Alexander (Eugeny Sidizhin), whose son Mickey (Shalva Iashvili), also 14, has a crush on Sybille. During this summer of the magical eclipse - stunningly photographed by Phedron Papamichael - Sybille promises Mickey 100 kisses. Since he only got 73, the rest of the story is about the 27 Missing Kisses - and what happens when a screening of a Emmanuelle film at the local armaments factory turns the town upside down. A tragicomedy, with an unexpected twist at the end.

\section{Die Unberührbare (No Place to Go, Germany), Oskar Roehler}

Oskar Roehler's Die Unberührbare follows the same route to the Directors' Fortnight taken by another postwall Berlin film a year ago: Andreas Kleinert's Wege in die Nacht (Paths in the Night). Ten years after the fall of the wall, No Place to Go comes across as entirely appropriate to help rectify some of the imbalance in measuring the cross-border cultural significance of that historical event. For although TV sets the world over were flooded with images of cheerful euphoria on the 9th of November 1989, there were some who were sceptical - others, bitterly disappointed - to see the utopia of a genuine socialist life come crashing down before their eyes.

One of these was the West German writer Gisela Elsner - named "Hanna Flanders" in the film (portrayed brilliantly by Hannelore Elsner) - who in real life was the mother of writer-filmmaker Oskar Roehler. In 1964 Gisela Elsner was hailed as the author of a bestseller: "Die Riesenzwerge" (The Big Dwarfs), a searing portrait of West German society. Based in Munich and a member of Communist Party, she was praised for her critical pen by leftists in the West and saw her novels published in the East. On November 9th, however, her GDR publisher in East Berlin (Michael Gwisdek in a memorable cameo) is only interested in toasting the fall of the wall. Worse for Flanders: upon her unexpected arrival in East Berlin, he doesn't care a hoot about Hanna's existential problems and suicidal frame of mind. For that matter, neither do her son, nor her ex-husband, nor her parents (whom she visits to beg for money), nor her erstwhile friends and colleagues.

No Place to Go is both a legacy and a requiem. Shot in stunning black-and-white (Hagen Bogdanski), the film unfolds psychologically like a dream imploding into the blinding light of a nightmare. It's also a passion play, one with clearly marked dramatic stations in the agony of a persona. The viewer accompanies a wounded Hanna on a Bergman-like journey into the self. Roehler portrays her as a vain woman, a writer too proud to admit she was ever wrong, a schizophrenic who smokes one cigarette after another, an eccentric poetess with heavily painted eyes under a Cleopatra-wig, a mother who had abandoned her husband and son (three 
years after his birth) "because they disturbed me at work." But he does so with love, with understanding, with forgiveness.

As a screenwriter and novelist in his own right, Oskar Roehler (b. 1959) didn't make much of a critical splash with his previous auteur films: the documentary Hard (1995), the features Gentleman (1995), Sylvester Countdown (New Year's Eve Countdown) (1997), Latin Lover (1998, tele-feature), and Gierig (Greedy, 1999). No matter, No Place to Go has changed all that.

\section{Werckmeister Harmoniak (The Werckmeister Harmonies, Hungary-Germany-France), Béla Tarr}

Bela Tarr - need it be said? - is Hungary's leading avant-garde, experimental filmmaker. For who else but Béla Tarr would spend three years (1991-94) to bring Laszlo Krasznahorkai's 1985 novel Satantango to the screen in an hypnotic tour-de-force? And who else but the Hungarian visionary would patiently spend another four years (1996-2000) on Werckmeister Harmoniak, a two-hour-plus screen version of Krasznahorkai's 1989 novel The Melancholy of Resistance?

"I just like working with Laszlo - we complement each other," Bela answered with a shrug when queried at the Budapest Festival of Hungarian Films why he has been collaborating with Krasznahorkai on four productions over the last twelve years. Laszlo Krasznahorkai, born 1954 in Gyula, studied copyright law and literature at the universities in Szeged and Budapest, spent his socialist days living and working odd jobs in towns across Hungary - then, at 30, penned "Satan's Tango" and became a freelance writer. Bela Tarr, born 1955 in Pecs, made several amateur films, graduated from the Budapest Film Academy (1981), worked at the Bela Balázs Studio, was a founding member of short-lived Tarsulas Film Studio (1981-85) - then met Krasznahorhai to collaborate as a screenwriter-director team on the five-hour Damnation (1987), the short feature The Last Boat (1989) (an episode in the City Life series sponsored by the Rotterdam festival), the seven-and-a-half-hour Satantango (1994), and now the two-and-a-half-hour The Werckmeister Harmonies.

From an aesthetic viewpoint, Damnation - Satantango - Werckmeister Harmonies form a stylistic trilogy of some 15 collective hours. All photographed by Gabor Medvigy in striking black-and-white images, they come across as apocalyptic allegories pegged to dismal, downbeat, isolated, film-noir settings: a mud-splattered nightclub called "Titanic Bar" in Damnation, an abandoned agricultural machinery plant in Satantango, and a small provincial town on the frosty Hungarian Plain in The Werckmeister Harmonies. In each tale a stranger happens upon the scene as a conman "Messiah" to stir things up.

In The Werckmeister Harmonies the arrival of a great stuffed whale in a circus tent draws crowds from far and wide - and tension mounts with the presence of the mysterious "Prince" hiding behind the whale. Why this particular setting? Just before he started on The Werckmeister Harmonies - featuring a trio of German actors: Lars Rudolph, Peter Fitz, and Hanna Schygulla - Bela Tarr made a video short for Hungarian TV titled Journey on the Great Hungarian Plain (1995).

\section{Koroshi (Film Noir, Japan), Masahiro Kobayashi}

For as long as one can remember, film noir - pegged to the American "black film" of the 1940s and reinterpreted by Jean-Pierre Melville for French cinema in the postwar era - has been one of the mainstays at the Cannes festival. In 1998, for instance, the Certain Regard programmed back-to-back Darezhan Omirbaev's Tuer à gages (Killer, Kazakhstan-France), winner of the first Fondation GAN prize, and György Féher's Passion (Hungary), a free-style adaptation of James M. Cain's seminal hard-boiled detective story "The Postman Always Rings Twice" - first adapted to the screen by French director Pierre Chenal under the title Le dernier tournant (The Last Bend, 1939) and filmed twice in Europe and twice in the United States. This year, you could see a pair of film noir entries again: Dito Tsintsadze's Lost Killers (Germany) in the Certain Regard and Mirashiro Kobayashi's Koroshi in the Directors' Fortnight.

Born 1964 in Tokyo, Masahiro Kobayashi tried his luck first as a singer and composer, then shifted to screenwriting and directing. Among his scripts filmed by other directors, The Yellow Donkey That Has No Name was awarded the Kido Prize in 1982. His two feature films, Closing Time (1996) and Bootleg Film (1998), could be seen at several international film festivals. As for this third feature Koroshi, it's a story set in the north of Japan that was inspired by Jean-Pierre Melville's The Samurai (1967), a key crime film in the collection of the French auteur who freely confessed that in his youth he was both "formed and deformed" 
by American gangster movies and novels. In The Samurai Melville broke with the American tradition by depicting a hired killer (Alain Delon) as a man of honour along the lines of the Japanese samurai tradition: when defeated, he is prepared to face the consequences and commit suicide.

Mirashiro Kobayashi's Koroshi offers yet another twist to the aesthetics of the film noir tradition: this time the killer is a gentle and honest man from the honourable, family-dedicated middle-class. Yuhi Hamazaki (Ryo Ishibashi), - "a typical Japanese salaried man," states Kobayashi - gets laid off from his job in the snowbound north during the recent Japanese recession. Like many of his kind, he hangs around with a heavy heart and purposely avoids painful explanations to his wife, who keeps sending pocket-money to their daughter studying in Colorado. One day, a stranger offers him a deal: to kill someone, in return for a job. He accepts - to find, after the first killing, that he's getting a new kick out of life. So he becomes a hitman, for better or for worse. Strikingly photographed (camera Akira Sakoh) against a crisp wintery landscape, Korosh $i$ is a tale in which the narrative is gradually engulfed by the images.

\section{Pane e Tulipani (Bread and Tulips, Italy-Switzerland), Silvio Soldini}

Winner of nine "David di Donatello" awards this year - amounting to a clean sweep: Best Picture, Best Director, Best Screenplay, Best Camera, Best Actress, Best Actor, Best Supporting Actress, Best Supporting Actor - Silvio Soldini's Bread and Tulips leaves little doubt that its writer-director is one of Italy's leading directorial talents with a knack for collaborating with leading screen personalities. Screenwriter Doriana Leondeff has been working with Soldini since his feature film Le Acrobate (The Acrobats, 1997) and is the same who co-authored Mimmo Calopresti's La Parola amore esiste (The Word Love Exists, 1998), the opening night entry at the 30th Directors' Fortnight. As for cameraman Luca Bigazzi - awarded Best Photography at the 1995 Venice festival for Gianni Amelio's Lamerica - he was given his first job as cinematographer by Soldini on Paesaggio con figure (Landscape with Figures, 1983), a 16mm short feature film invited to several festivals, and they have collaborated on seven occasions since.

Born 1958 in Milan, Soldini at 24 made the first of eight short features, setting up his own Monogatari production company in 1984 shortly after winning festival recognition for Landscape with Figures. He's also made eight documentaries over the past 15 years. But it was the four feature films, neatly constructed social dramas with tragicomic touches, that brought him recognition at home and abroad: L'Aria serena dell'Ovest (The Serene Climate of the West, 1990), Un'Anima divisa in due (A Soul Divided in Two, 1993), Le Acrobate (The Acrobats, 1997), and Pane e Tulipani.

Rosalda (Licia Maglietta), a provincial housewife, accompanies her family on a sightseeing trip - and gets accidentally left behind. Hurt that she has been overlooked and left alone again, she decides on the spur of the moment to head for home on her own without waiting for her husband and sons to return. Before she knows it, however, she finds herself on the way to Venice - and decides to extend her day of freedom into a prolonged holiday! Not only that, she gets a job as a florist, shares an apartment with an Icelandic waiter Fernando (Bruno Ganz), makes friends with the beautician Grazia (Marina Massironi), and rediscovers her passion for playing the accordion. Meanwhile, her irate husband sends the quirky detective Constantino (Giuseppe Battiston) to look for her. Remember Federico Fellini's Lo Sceicco bianco (The White Sheik, 1952)? Well, Bread and Tulips is a variation on the same theme.

\section{Les Fantômes des trois Madeleine (The Three Madeleines, Canada), Guylaine Dionne}

"The story of these three women named Madeleine was born six years ago, when I was vacationing at a friend's house in Biot, a small village a few kilometers away from Cannes," says Guylaine Dionne about Les Fantômes des trois Madeleines. "For me this film has been one of the most interesting and fascinating challenges of my young career. I carried this film with me, inside me, for so long, looking to instill into each detail a sparkle of life." Take her at her word, and this Camera d'Or entry was conceived almost in its entirety just down the road from Cannes.

Producer, director, and screenwriter of The Three Madeleines, Guylaine Dionne was born in Quebec, studied cinema at Concordia University in Montreal, and spent ten years making short films and documentaries mostly for television. Her short feature Les Frissons d'Agathe (Agatha's Shivers, 1989) received the Panavision Canada Award, among other citations of recognition. Her documentary series Amérique 500 (1991-93), filmed in ten countries across the Americas, received the Gémeaux Award for Best Documentary Series.. Other documentaries include Les Rêves secrets des Tarahumaras (The Secret Dreams of the Tarahumaras, 
1993), the documentary series Iles d'inspiration: Félix Leclerc (Isles of Inspiration: Félix Leclerc, 1999), and Jess Goes West (2000) in the documentary series titled Les histoires oubliées (Forgotten History).

The Three Madeleines is the story of three generations of women narrated within the context of a road-movie. During a trip from Montreal to the Gaspé region, each member of the family - grandmother, daughter, granddaughter - talks openly about her pasts and her dreams. The grandmother Mado (France Arbour) is still searching for traces of the man she loved in her youth, the father of her daughter born out of wedlock and given up for adoption. This daughter is Marie-Madeleine (Sylvie Drapeau), who herself as a liberated mother and professional photographer wants to face down her own fears and open herself up to a daughter. And the 17-year-old Mado (Isadora Galwey), who has never met her father (he lives in Germany), reminisces on her past as a carefree blithe spirit in love for the first time. Put these memories and dreams altogether, says Guylaine Dionne, and you have a Bergman-like, journey-into-the-soul road-movie: "We are talking here about family - a broken family, true, but one that is nonetheless full of poetry and hope." And when the going gets tired, tough, and tedious, when the confessional disclosures become repetitive, there's always the rugged picturesque Gaspé region to provide an appropriate visual backdrop.

\section{Lumumba (Belgium-France-Germany-Haiti), Raoul Peck}

Of the three legendary postwar Marxist revolutionaries - Africa's Patrice Lumumba, Southeast Asia's Ho Chi Minh, and South America's Che Guevara - the name of the assassinated Patrice Lumumba (1925-1961), co-founder of the "Mouvement National Congolais" (MNC), was anything but esteemed in Zaire (formerly Belgian Congo) until proclaimed a national hero in 1966. The books on his life and times were reopened a decade ago, when Haitian director Raoul Peck made Lumumba - Death of a Prophet (1991), a documentary that helped considerably to clarify details about the betrayal, arrest, torture, and murder of the political activist and deposed prime minister of the new Democratic Republic of Congo in January of 1961. Some observant critics maintain that Peck's documentary, recipient of the San Francisco Golden Gate Award and programmed by more than 40 festivals, influenced the making of Spike Lee's Malcolm X a year later.

Born 1953 in Port-au-Prince, Haiti, Raoul Peck lived for a time in Zaire, worked as a journalist and photographer, studied economics at the Free University of Berlin, graduated from the Berlin Film Academy (1988), made a dozen shorts and features from his Velvet production base in France and Germany, and served until recently as the Minister of Culture of Haiti (1995-97). His L'homme sur les quais (The Man by the Shore, 1993), set in Haiti of the Duvaliers, competed at Cannes, and his Corps plongés (It's Not about Love, 1998), about a Haitian diplomat exiled in New York during the military coup, was invited to compete at Montreal.

"After 18 months of relentless political struggle as Minister of Culture for my country," states Peck, "I decided to return to (the story of) Lumumba and set the record straight, 37 years after the fact, about a murder-cum-sacrifice. It's also a matter of transcending my own griefs, regrets, and still-burning anger." For Lumumba he chose a multi-level chronological approach, rather than a linear narrative, covering three time-scales: today's 30th anniversary of independence, the 1961 Congo crisis, and Lumumba's formative years. We see a charismatic orator rise from menial jobs as postal employee and beer salesman to become the leader of the MNC Party and win election as prime minister of the new Congo. And we meet the allies - Tshombé, Mobutu, Kasavubu - who betrayed and delivered him to the firing squad, then tried to wipe out all traces of his memory among the people. "A Shakespearean drama" (Peck) - sometimes a political pamphlet, often theatrical and melodramatic, always concise and with the power to communicate.

\section{La Captive (The Captive, France-Belgium), Chantal Akerman}

He's back in Cannes again - Marcel Proust (1871-1922) - and on the French classic writer's name alone francophiles flocked to the screening of Chantal Akerman's La Captive, based loosely on his La Prisonnière (originally titled Sodome et Gomorrhe III and published posthumously as The Prisoner in 1923). So it was last year for Raoul Ruiz's Le Temps retrouvé (Time Regained), based on the last of his uncompleted seven-volume work $\grave{A}$ la recherche du temps perdu (Remembrance of Things Past, written between 1913 and 1927). The same thing happened back in 1981, when Percy Adlon's first feature film Célèste appeared in the German series -to draw an overflow French crowd from the street to the Cinéma Le Français on the Rue d'Antibes. Based on an autobiography of Proust's housemaid, who recounted the living and working habits of the French writer, Célèste starred Eva Mattes in the title role. Two years later, Volker Schlöndorff's Eine Liebe von Swann (Swann's Way, 1983), a screen adaptation of Du côté de chez Swann (published 1913), the 
first book in Proust's remembrances, was scripted by Peter Brook and Jean-Claude Carrière into an opulent international co-production starring Jeremy Irons, Ornella Muti, Alain Delon, Marie-Christine Barrault, and Fanny Ardant.

Chantal Akerman, born 1950 in Bruxelles, ranks as one of the world's leading women filmmakers, equally at home in America as she is in Europe. Her first film, Saute ma ville (Blow Up My Town, 1968), was made at 18 and starred herself in a kind of letter-writing format. That spurred at least one leading critic of feminist cinema to view her oft-employed epistolary style as "a series of love letters to the mother". A better index of her vision and style, however, comes from an interview: "When I saw Jean-Luc Godard's Pierrot le fou, I realized that film was a language as strong as literature can be. I have not seen Pierrot le fou since that time, so I cannot even say what it was that had such an effect on me, but it was like talking to one person."

Among her 35 films over the past 25 years - shorts, documentaries, features - are some quite extraordinary contributions to both personal and feminist cinema: Jeanne Dielman, 23 quai du Commerce, 1080 Bruxelles (1975), Dis-moi (Tell Me, 1980), Histoires d'Amerique (1989), and the semi-autobiographical Portrait d'une jeune fille de la fin des années 60 à Bruxelles (Portrait of a Young Girl at the End of the 1960s in Brussels, 1993). Her latest, The Captive, is thus as much Akerman as it is Proust. Instead of making the acquaintance of Marcel and Albertine in the fifth book of Proust's remembrances, we met the bisexual Ariane (Sylvie Testud), who lives with rich and jealous Simon (Stanislas Merhar) in a plush Paris apartment. Simon, a possessive type, wants to know everything about Ariane and her girlfriends, so he follows her everywhere on foot and by car through Paris and subjects her to endless questioning. The fact that Ariane has a taste for women only unnerves Simon all the more, for he now feels powerless to deal with a woman leading a double life. A Proustian dilemma to the core, it's handled well and transplanted neatly by Akerman to the modern world today.

\section{Cuba Feliz (France-Cuba), Karim Dridi}

Cuba Felix, a song composed by Armandito Machado, is just one of 22 in the film that bears the same title and nearly all are sung by Miguel Del Morales, better known as "El Gallo" (the Rooster). Originally Karim Dridi planned to use "El Gallo" only for two or three days of shooting in Cienfuegos and Trinidad. But when 76-year-old vagabond-troubadour proved to be such an asset - not only does he know scores of Cuban songs by heart, but he also sings them with a lilt in his voice that speaks of joy and suffering - Dridi and his screenwriter Pascal Letellier, a noted authority on Cuban music and artistic director of several festivals devoted to world cultures, decided to take him with them on this "road movie musical" across the length and breadth of Cuba.

Born 1961, Karim Dridi has a solid festival record. All four of this feature films were programmed at major festivals: Pigalle (1994) at Venice, Bye- Bye (1995) in the Certain Regard at Cannes, Hors Jeu (1998) at Locarno, and now Cuba Felix in the Directors' Fortnight at Cannes. In addition he has made a number of short films, plus documentaries for Arte on Citizen Ken Loach (1997) and An Impression of South Africa (1996).

"I hardly knew anything about Cuba, and even less about its music, despite the fact that it was on the air all day," admits Karim Dridi. "I wanted to go backstage, behind the scenes, to see what was hidden behind this musical genre and its cliches. I asked my friend Pascal Letellier, who knew Cuba well, to dive with me into this great island." This was also the first time Dridi was behind the camera: "We were a team reduced to the essentials. The film was shot from day to day with a handheld camera and a single microphone fixed to a boom. Little by little, I found my perspective merging with that of Gallo in the picture."

Asked to describe Cuba Felix, Dridi called it a "musical voyage." Along the way they met some native musicians who are already legends among their people: Pepin Vaillant, Mirta Gonzales, Anibal Avila, Alberto Pablo, Armandito Machado, and Mario Sanchez Martinez (known simply as "Juan"). The trio would sometimes spend entire days in people's homes, waiting until the music and energy unite in a moment that has to be captured. "It's like making love," says Karim Dridi. But it's also an affirmation - to life, to a musical tradition, to a culture about to fade forever into the past.

L'Affaire Marcorelle (The Marcorelle Affair, France), Serge Le Péron

"We are all guilty, myself more than the others," said Dostoevsky in the introduction to his classic "Crime and 
Punishment." The quote is used to set the stage for Serge Le Péron's L'Affaire Marcorelle, a psycho-drama featuring a prosecutor who suffers from chronic nightmares and walks the edge between dream and reality. Of all the great Russian writers, only Dostoevsky's works continue to speak eloquently to the agonizing fears and nightmarish phobias of the present day - as The Marcorelle Affair dramatically underscores.

Like filmmaking colleagues before him, Serge Le Péron came to cinema after serving on the editorial committee for Cahiers du Cinema (1976-84). Then, following another stint (1986-90) as a columnist and editorin-chief for the magazine Cinéma Cinémas, he joined France 3 to make a series of documentaries and telefeatures: De la terre à la lune (From Earth to Moon, 1989), Sesame ouvre-toi (Open Sesame, 1990), Le Nouvel ennemi (The New Enemy, 1994), L'Affaire Spaggiari (The Spaggiari Affair, 1997), Bruay: histoire d'un crime impuni (Bruay: Story of an Unpunished Crime, 1998), and Musiques de Films: Joseph Kosma (Music for Films: Joseph Kosma, 2000).

One of these documentaries, Bruay: Story of an Unpunished Crime, dealt with the Bruay affair in Artois. Le Péron: "In this affair, set in the early 1970s, the period of the so-called red judges, the judge Pascal presented himself as defending the cause of the people against the bourgeoisie, and he was supported by the Maoistes of the period." Also, while making the documentary The Spaggiari Affair, Le Péron recalls meeting a lot of judges "who were protected by their rituals, their class, their caste, their culture." Taking these factors into consideration, the cause of true justice is placed in question.

In The Marcorelle Affair François Marcorelle (Jean-Pierre Léaud), a prosecuting judge who in his youth was a revolutionary with ideals, meets Agnieszka (Irène Jacob), a Polish waitress, on a lonely night in a Turkish restaurant in Cambery and accompanies her to her place. A series of bizarre events lead to the murder of the woman's father, but did Marcorelle really commit the crime? So he believes. That is, until his doctor friend convinces him that he is living one of his chronic nightmares - brought about no less by visits to revivals at the local arthouse (!) - and that the crime never happened at all. Sure that the events were all too real to have been dreamed, Marcorelle looks for proof - and finds what he's seeking one afternoon in the darkness of the movie theatre. Dostoevsky aside, Le Péron has fashioned a witty, sophisticated suspense thriller worthy of Clouzot and Hitchcock.

\section{La Chambre obscure (The Dark Room, France-Luxembourg-Italy), Marie-Christine Quester- bert}

If the title of Marie-Christine Questerbert's La Chambre obscure sounds familiar, then you guessed right - it's a Boccaccio's tale found in the Decameron and set in 14th-century Italy. Queried about her attraction to the period and the story, and whether she might have seen Pier Paolo Pasolini's Decameron (1971), Questerbert responded: "The 14th century was a period in which everything was romanticized: God, the devil, history, life and death. It is not a chanson de geste, nor a popular tale in the way that Pasolini understood it. Rather, it's a tale of chivalry in which the feminine character sets out into the world. She is no longer the lady waiting at her window for feats of prowess to be accomplished on her behalf. The obstinate rival of tradition and authority is desire. She takes it upon herself to embody this urge, unsure that the boy will see it through."

As for the story itself, it has a Shakespearean twist to it and comes across as distinctly modern. Young Alienor (Caroline Ducey) throws medieval mores to the wind by following the dictates of her heart. One day, she takes her own fate into her hands by risking her life to cure the King of France of a contagious illness. Offered a reward in return, she asks the King for permission to marry Bertrand de Roussillon (Melvil Poupaud), whom she has loved since childhood. The King agrees. But Bertrand feels compromised and refuses to consummate the marriage. Instead, he runs off to Tuscany - pursued by Alienor. And here's the Boccaccio twist: she disguises herself as a young Italian woman to entice the duped Bertrand into a passionate confession of love. Asked if she ever considered setting the story in today's world, Questerbert admits: "I considered it, but I think it is more important that Alienor is part of a world in which institutions are still aristocratic, and power is sacred."

Marie-Christine Questerbert studied philosophy and art before directing her first short film Les Filles hereditaires (The Hereditary Girls, 1982), after which she found herself in demand as an actress: Une Adventure de Billy le Kid, with Jean-Pierre Léaud, and Anatomie d'un rapport, in which she played the lead role. After seeing a Michael Snow experimental film, she discovered a passion for photography and screenwriting, went 
to Italy to meet Cesar Zavattini and Tonino Guerra, and wrote a book on "The Italian Screenwriters." In Italy she made another short film, Cremonini, images reflets (Cremonini, Reflected Images, 1996), then sat down to read Story III/9 from the Decameron. Daniéle Dubroux, a talented writer-director in her own right, collaborated with Questerbert on the screenplay.

\section{Petite Chérie (Little Darling, France), Anne Villacèque}

"The film was born of a feeling, rather than an actual story," says Anne Villacèque of Petite Chérie, her first feature film after two minimalist documentaries on the same general theme that leaned towards a fictional treatment. Born 1963 in Toulouse, Villacèque was awarded the Prix Jean Lods (a young talent prize) for 3 histoires d'amour de Vanessa (3 Stories of Vanessa in Love, 1996), documenting the coming-of-age of a teenage girl between the ages of 13 and 16. Les Infortunes de la vertu (The Misfortunes of Virtue, 1998) takes its title cue from the first philosophy essay by newly enrolled university students. Both were coproductions with Arte France Cinema, as is her work-in-progress documentary Marrakech-Toronto, un aller simple (Marrakesh-Toronto, One-Way Ticket).

"I felt a fiction film would allow me to approach similar subject matter differently," adds Villacèque, "by expressing a hidden, negative side. And so Petite Chérie is firstly the embodiment of violent and diffuse feelings: the anxiety of loneliness, the loathing of an indistinct family group, the fascination for ordinary or disturbing details." The story was inspired by an item in a newspaper, read six or seven years ago, that "stuck in my mind and then altered itself over the months and years without my ever trying to check on the exact events."

Little Darling is the story of 30-year-old Sybille (Corinne Debonnière), a lonely woman still living with her lackluster parents and given to romantic dreams nourished by a regular diet of pulp fiction. One day, she looks up from her favourite novel to gaze into the eyes of Victor (Jonathan Zaccaï), a passing lothario and falls passionately in love with him on the spot. Taking him home, she finds that her parents, too, are entranced by the stranger. So he moves in - and stays. Soon nothing is too good for Victor: Sybille's mother changes the decor of her beauty parlour, and her father is led by the nose into a shady business deal. The situation is rapidly deteriorating - until, finally, Sybille decides she has to act to save both her illusions and her newly found happiness. As quirky as the story sounds, Anne Villacèque argues, rather convincingly, that life can be just as absurd - sometimes even worse.

\section{Le Secret (The Secret, France), Virginie Wagon}

Back in 1998, Erick Zonca's La Vie rêvée des anges (The Dream Life of Angels), the first feature of a 44-yearold writer-director, explored the subtle relationship between two young women who do not quite experience the real world like the rest of us? Elodie Bouchez and Natacha Régnier shared the Best Actress Award at Cannes for their performances as "outsiders" in that film. Now, two years later, Virginie Wagon, who collaborated as screenwriter on The Dream Life of Angels, is present with own first feature: Le Secret.

Born 1965, Virginie Wagon contributed reports and documentation for various press agencies before meeting Erick Zonca. She collaborated with him on all three of his short films; Rêves (Dreams, 1992), Eternelles (Eternal, 1994), and Seule (Alone, 1996) - the preludes to his The Dream Life of Angels - in addition to Zonca's recent Le Petit voleur (The Little Thief). Along the way, she made a short film of her own: Grandir (1995), the title referring to making oneself look taller with shoes or clothes. Grandir played several festivals and set the stage for The Secret.

Marie (Anne Coesens), a 35-year-old married for twelve years to François, whom she loves and who is the father of her two-year-old son Paul. François want to have another child, but Marie is not at all sure although she confesses to herself she doesn't really know why. Marie earns some money on the side by selling encyclopaedia from door to door. One day, she knocks on the door of a villa - and meets Bill (Tony Todd), a 50-year-old black American who never goes out and can hardly speak a word of French. The first clumsy, hesitant meeting leads to another, and soon they are beginning to enjoy conversations together. In fact, Marie likes to prolong them, for now she can open up, talk about herself, and let out a long suppressed secret. The encounter, as innocent as it was in the beginning, leads to the predictable spiritual crisis.

Faites comme si je n'étais pas là (Pretend Like I Wasn't There, France-Italy), Olivier Jahan Olivier Jahan is a familiar name at Cannes. He served as assistant deputy and presse attaché to Pierre-Henri 
Deleau at the latter's 30th farewell Quinzaine des Réalisateurs in 1998. Now he's back at the Directors' Fortnight with his first feature film: Faites comme si je n'etais pas là. Besides collaborating as program director at several festivals, Jahan has made a handful of short films seen at festivals in Cannes, ClermontFerrand, Grenoble, and Pantin: Parlez après le signal sonore (Speak After You Hear the Tone, 1994), Comme un dimanche (Like a Sunday, 1995), Au bord de l'autoroute (Along the Motorway, 1996), and Beaucoup trop loin (Very Far Away, 1998). For the most part, they are original, personal, inquisitive works by a writerdirector interested in the everyday and the affairs of young people.

In Pretend Like I Wasn't There a lonely, secretive, enigmatic teenager spends much of his time buried inside himself and spying on his neighbours across the way through his bedroom window. As Eric (Jérémie Rénier) retreats further into himself and his world of illusions, he becomes involved in a couple of shady deals on the side. Then things take a dramatic turn when a mysterious couple, Fabienne (Alexia Stesi) and Tom (Sami Bouajila), move into the building next door. For a thrill-seeking voyeur it couldn't be more opportune: what she sees is enticing, seductive, and satisfying to the libido, but in the long run psychologically disturbing. Eric's voyeuristic fantasies are now pushed to the limits, and he has to decide whether or not he really wants to return to the real world. If all of this sounds familiar, then you're right. At least one cinematic reference is the young voyeur in Krzysztof Kieslowski's A Short Film About Love (1988) in his Decalogue cycle.

\section{CRITICS WEEK CHOICES}

The oldest sidebar in Cannes dates back to 1962, when Cannes festival director Robert Favre Le Bret asked Louis Marcorelles, critic at Le Monde, to present at the festival a special screening of Shirley Clarke's The Connection (USA), a screen adaptation of Jack Gelber's play about drug addiction in Manhattan. Marcorelles obliged - and the Semaine de la Critique was born. This year, newly appointed director José María Riba, together with six colleagues (Laurent Akain, Claire Clouzot, Sylvain Garel, Jean Rabinovici, Giuseppe Salza, and Jacques Zimmer), screened 300 films before selecting 14 entries: seven features and seven shorts. The Critics' Week also made waves at Cannes 2000 by launching the films in the new Salle Buñuel venue atop the Palais des Festivals. Herewith some notes on the two French feature films:

\section{De l'histoire ancienne (About an Old Story, France), Orso Miret}

Orso Miret's De l'histoire ancienne stands out as a political statement on the rather distant past, yet one that's hard to ignore even today. Its theme, the French Resistance during the Second World War, has been tackled before by René Clément in the fiction documentary La Bataille du rail (The Battle of the Rails, 1946), a reconstruction of some exploits in the French Resistance, and by Marcel Ophüls in the documentary Hotel Terminus (Certain Regard, Cannes 1988), a compilation of eyewitness testimony about collaborators and victims in the French Resistance that surfaced during the time of the Klaus Barbie trial. Both films spurred discussion and sparked controversy. On one side of the ledger, there are the heroes of the Resistance whose honour is protected by family and friends. On the other side, there are the betrayers, the double-agents, the collaborators, even the innocent drawn into the maelstrom of fast-moving political events they cannot understand nor control, both during and after the war.

Awarded the prestigious Prix Jean Vigo 2000, An Old Story is Orso Miret's first feature film. Prior to this, he had made two shorts: Dans le forêt lointaine (In the Far Away Forest, 1995) and Une Souris verte (A Green Mouse, 1996), the latter awarded at the Clermont-Ferrand film festival. In About an Old Story we first follow in the footsteps of Olivier (Stéphane Bierry), a secondary school teacher, who is working on his doctorate about members of the French Resistance who had been shot during the WWII. To help with the research, Olivier turns to Guy (Yann Goven), his best friend who works in a bookshop. Since Guy's father was in the Resistance and had miraculously escaped a collective execution, Olivier wants to meet him. The meeting is put off - then, suddenly, the father dies. The death of a former hero now turns the investigation into the past upside down. Moreover, Guy feels guilty about the whole affair and now wishes to redeem the honour of his father, if at all possible. And not just he - Guy's sister and brother can hardly cope with an inconsolable mother, who soon has to be admitted to the hospital as a pathological case. Guy, faced with one personal failure after another, decides to commit suicide by blowing himself up in a right-wing bookshop.

Les Autres filles (Girlfriends, France), Caroline Vignal

Caroline Vignal's Les Autres filles introduces a talented woman director who graduated with a degree in 
linguistics and modern literature before entering FEMIS, the French film school, to study screenwriting. Her first short feature, the 11-minute Solène change de tête (Solène Changes Her Face, 1998), was an immediate success and received invitations to several festivals. Her second short feature, Roule ma poule (Take It Easy, 1999) proved to be even more successful by winning three top awards: the Prix Louis Daquin for the screenplay, the Prix Canal Plus at Grenoble, and the Special Jury Prize at Alès. Both shorts in turn prepared the way for Girlfriends, a project she began while studying screenplay writing at FEMIS. "You have to build up your confidence before taking that important step towards a first feature film," Caroline Vignal said. "The short films permitted me to demystify the theme and to swallow a bit of the fear before shooting a feature."

In Girlfriends Solange (Julie Leclercq), a shy 15-year-old from a village in southern France, leaves home and her parents to enroll at a trade school in Toulouse to learn how to become a hairdresser. She strikes up a friendship with Gary (Benoîte Sapim), who is completely her opposite: fun-loving, street-wise, chatterbox with a loud sense of humour. Through Gary she meets other girlfriends, who are in to boys, disco dancing, and changing the colour of their hair whenever the notion hits them. Solange wants to be like her girlfriends, save for one hitch: she's still a virgin, and it weighs on her like a millstone. Once she decides to get rid of the burden, the next question is how. More than a tale of sex and teenagers, this one has enough twists in it to surprise, titillate, and tug at the heart.

\section{Author Information}

Ron HOLLOWAY (1933-2009) was an American critic, film historian, filmmaker and correspondent who adopted Europe as his home in the early fifties and spent much of his life in Berlin. He was an expert on the study of German cinema and against all odds produced, with his wife Dorothea, the journal German Film, keeping us up-to-date with the work of directors, producers and writers and the showing of German films around the world.

In 2007, Ron Holloway and his wife were awarded the Berlinale Camera Award. Ron also received the Bundesverdienstkreuz (German Cross of Merit), Polish Rings, Cannes Gold Medaille, the American Cinema Foundation Award, the Diploma for Support of Russian Cinema and an honorary award from the German Film Critics' Association.

Ron was also a valued contributor to Kinema for the past fifteen years. 